\title{
JUURNAL.RU
}

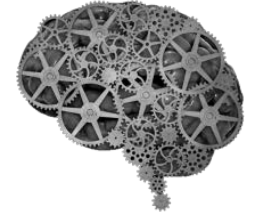

COMPANY GROUP "INTELLEKT"

\author{
Маль Г.С., Кувшинова Ю.А. \\ Курский государственный медиџинский университет \\ Курск, Россия
}

doi: 10.18411/lj2016-6-2-09

\section{Применение гиполипидемических препаратов с помощью генетических маркеров у больных ибс}

doi:10.18411/lj2016-6-2-09

Сердечно-сосудистые заболевания (СС3) лидируют среди причин смертности и инвалидности взрослого населения экономически развитых стран мира и имеют тенденцию к прогрессированию. Учитывая, что метаболизм всех лекарственных средств в организме человека генетически детерминирован, то применение современных фармакогенетических тестов для подбора индивидуальной дозы гиполипидемического препарата приобретает все большую актуальность для персонализированной медицины.

Материалы и методы: Под наблюдением находились 118 больных ИБС с первичной изолированной гиперхолестеринемией (ГХС) или сочетанной гиперлипидемии (ГЛП) в возрасте от 41 до 60 лет $(55,7 \pm 2,9$ и 56,2 $\pm 3,2)$, из них 38 пациентов составили контрольную группу. А так же были проанализированы частоты генотипов по полиморфному маркеру C3435T гена MDR1 в группах больных ИБС, принимавших статины II и IV поколений.

Мы определили степень изменения всех показателей липидного спектра у больных, принимавших симвастатин (из них генотип СС имели 12 пациентов, СТ - 17 пациентов, ТТ -11 пациентов) и розувастатин (генотип СС имели 11 пациентов, СТ - 19 пациентов, ТТ -10 пациентов). 
Наиболее выраженный гиполипидемический эффект симвастатина в дозе 20 мг/сут наблюдался у лиц с ИБС, несущих генотип ТТ по сравнению с пациентами, имеющими генотипы СС и СТ. Эффективность симвастатина по показателям ХC, ХС ЛНП, ТГ, АИ была достоверно выше в группе лиц, имеющих генотип ТT. Можно сказать, что значительное снижение всех атерогенных фракций липидного спектра у пациентов с генотипом ТТ по полиморфному маркеру C3435T гена MDR1 было главной причиной, приводящей к большей эффективности симвастатина.

В нашем исследовании не было обнаружено связи между полиморфным маркером C3435T гена MDR1 и развитием большего гиполипидемического эффекта розувастатина у пациентов с генотипом ТТ, чем с генотипами СТ и СС. У пациентов с генотипами СС, ТТ и СТ эффективность розувастатина по всем показателям липидного спектра достоверно не отличалась. Аллельный вариант TT гена MDR1 у больных ИБС не явился генетическим фактором предрасполагающим к выраженной эффективности розувастатина.

Полученные результаты описанной взаимосвязи генотипа по полиморфному маркеру C3435T гена MDR1 и гиполипидемического эффекта у больных ИБС с различными типами ГЛП показали неоспоримый вклад знаний о генетической гетерогенности субпопуляции в целях индивидуализации фармакотерапии. 


\section{Литература:}

1. Демографический ежегодник России. 2013: стат. сб. - М.: Росстат, 2013. $543 \mathrm{c}$.

2. Дзвониская, В.Н. Влияние индивидуальных особенностей окислительного метаболизма и генетических факторов на эффект гиполипидемической терапии у больных ишемической болезнью сердца: автореф. дис. канд. мед. наук: 14.03.06 / В.Н. Дзвониская. - Курск, 2011. - 22 с.

3. Оказание помощи при хронических состояниях. Взгляд с позиций системы здравоохранения / под ред. Ellen Nolte, Martin McKee; Всемирная организация здравоохранения, от имени Европейской обсерватории по системам и политики здравоохранения. - [Женева], 2011 - 256 с.

4. Global atlas on cardiovascular disease prevention and control / WHO. Geneva, Switzerland, 2011. - 164 p.

5. Non-high-density lipoprotein cholesterol and apolipoprotein B in the prediction of coronary heart disease in men / P. Pignoli, E. Tremoli, A. Poli [et al.] // Circulation. - 2005. - Vol. 112. - P. 3375-3383. 